Z. klin. Chem. u. klin. Biochem.

10. Jg. 1972 , S. $164-168$

\title{
Radioimmunoassay for Plasma Testosterone
}

\author{
By E. NIEsChLAG ${ }^{1}$ ) and D. L. LoRIaux \\ National Institute of Child Health and Human Development, Reproduction Research Branch, Bethesda, Maryland
}

(Eingegangen am 16. August/30. September 1971)

A sensitive tadioimmunoassay for plasma testosterone has been developed. The antisera used were obtained by immunizing rabbits with testosterone-3-albumin or testosterone-3-hemocyanin conjugates. Applying a new immunization technique antibodies were obtained in high titer as early as four weeks after immunization. The standard curve of the assay extends over a wide range of dosages (0.025 to $10.0 \mathrm{ng}$ ). Reliability criteria are satisfactory. The assay compares favourably with competitive protein binding methods for testosterone.

Ein empfindlicher Radioimmunoassay für Plasma-Testosteron wurde entwickelt. Die verwandten Antiseren wurden durch Immunisierung von Kaninchen mit Testosteron-3-Albumin- oder Testosteron-3-Hemocyanin-Konjugaten gewonnen. Unter Anwendung eines neuen Immunisierungsverfahrens gelang es, Antikörper mit hohen Titern bereits vier Wochen nach der Immunisierung zu erhalten. Die Standardkurve des Assays erstreckt sich über einen weiten Bereich (0,025 bis $10,0 \mathrm{ng})$. Die Verläßlichkeitskriterien der Methode sind zufriedenstellend. Der Radioimmunoassay ist vergleichbaren kompetitiven Proteinbindungs-Methoden für Testosteron überlegen.

Attempts to produce antibodies against steroids date as far back as 1941, when Mooser and Grilliches (1) tried to immunize animals against androstenediol coupled to an azoprotein. Their experiments were unsuccessful, probably because the steroid-proteinesters were readily hydrolysed when injected into animals. ERLANGER and coworkers (2) prepared more stable steroid-protein-conjugates and were able to produce antisera. Despite the availability of steroid antibodies, however, radioimmunoassays for protein hormones were in use for almost a decade, before the principles of these assays were applied to steroid determinations. The first steroid radioimmunoassay to be described was for plasma estrogens (3). Since then, other immunoassays for estrogens $(4,5,6)$, aldosterone (7), testosterone (8) and progesterone ( 9 ) have been developed.

This paper presents a sensitive radioimmunoassay for plasma testosterone using a highly potent antiserum which was obtained by a new immunization technique. The standard curve of the assay is useful over a wide range of dosage.

\section{Materials and Methods}

Solvents were purchased in reagent grade from Baker Chemical Co. and used without further purification (diethyl ether, chloroform, methanol, ethylacetate, petroleum ether, dioxane, toluene).

Testosterone and all other steroids were obtained from Sigma Chemical Co. Testosterone-[1,2-3 $\mathrm{H}]$ with a specific activity of $0.25 \mathrm{mCi} / 1.6 \mu \mathrm{g}$ was supplied by the New England Nuclear Corp. The scintillation liquid consisted of Liquiflour and toluene in a proportion of $1: 19(\mathrm{v} / \mathrm{v})$. Liquid scintillation counting was done in a Packatd Tricarb scintillation spectrometer, model 4322.

A solution of $0.1 \%$ bovine gamma globulin fraction II (Schwarz) Mann.) in $0.9 \%$ saline served as diluent (suggested by Dr. K. J. Catr, personal communication). Precoated thin layer plates (Silica Gel F 254, $0.25 \mathrm{~mm}$, Merck AG) were used as supplied.

1) Recipient of a fellowship from the Deutsche Forschungsgemeinschaft.
Dextran coated charcoal consisting of $0.25 \%$ charcoal (Matheson Scientific Corp., CX 645, lot 288) and 0.25\% Dextran T-70 (Phatmacia) in diluent was used to separate bound from free steroid. (O-carboxymethyl)-hydroxylamine, tri-n-butylamine and isobutylchlorocarbonate were purchased from K \& K Laboratories, bovine serum albumin from Armour Pharmaceutical Co. and hemocyanin from Calbiochem. Complete Freund's adjuvant and Mycobacterium tuberculosis (killed, H $37 \mathrm{Ra}$ ) were supplied by the Difco Laboratories.

\section{Preparation of antigen}

Testosterone-3-(O-carboxymethyl)-oxime was prepared from tritiated testosterone of known low specific activity and (O-carboxymethyl)-hydroxylamine following the procedure of $E_{R-}$ LANGER and coworkers (2). The oxime was coupled either to bovine serum albumin or hemocyanin by a mixed anhydride reaction $(2,10)$. The testosterone-3-albumin conjugate contained 9 steroid residues per molecule, while the testosterone-3-hemocyanin conjugate contained 190 residues per molecule (assuming a molecular weight of 2 million for hemocyanin).

\section{Immunization}

Immunizations were performed according to the method of VAITUKaITrs and coworkers (11). Female New Zealand white rabbits were used and once injected intradermally at multiple sites with an emulsion of the testosterone conjugate, complete FrEUND's adjuvant and additional $M$. tuberculosis. Two animals were immunized with $75 \mu \mathrm{g}$ each of testosterone-3-albumin, and four animals were immunized with $100 \mu \mathrm{g}$ each of testosterone-3hemocyanin. Booster immunizations were not necessary.

\section{Sample preparation}

One $\mathrm{ml}$ of plasma from men or women was pipetted into $13 \mathrm{ml}$ glass stoppered centrifuge tubes. $1000 \mathrm{cpm}^{2}$ ) testosterone-[1,2- ${ }^{-3} \mathrm{H}$, equivalent to $8 \mathrm{pg}$ of testosterone and dissolved in $50 \mu \mathrm{l}$ methanol, was added and incubated for $15 \mathrm{~min}$. at room temperature after thorough mixing. The plasma then wàs extracted twice with $5 \mathrm{ml}$ diethyl ether from a freshly opened can. The ether phases were transferred to another $13 \mathrm{ml}$ glass tube and the extract was taken to dryness under an air jet in a water bath of $30^{\circ} \mathrm{C}$.

The residue was applied to thin layer plates with $2 \times 75 \mu \mathrm{l}$ methanol. The plates were divided into 6 equal lanes and a testosterone standard placed in the outer lanes. The plates were developed in

$\left.{ }^{2}\right) \mathrm{cpm}=$ Counts per minute. 
Für Ihr Gerinnungslabor

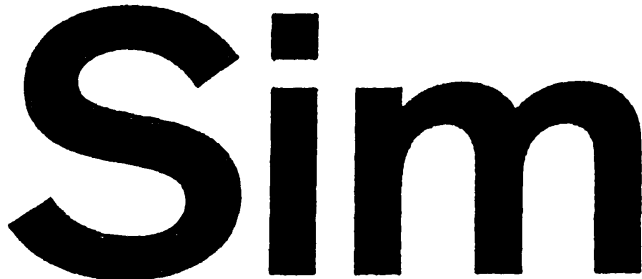

lyophilisiertes Thromboplastin
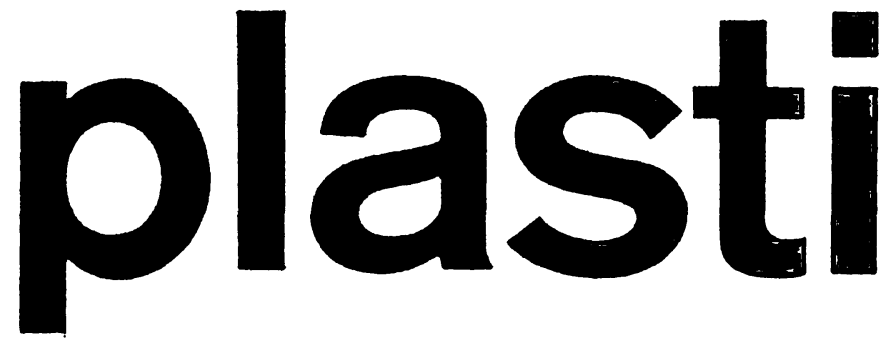

(®) mit Calcium
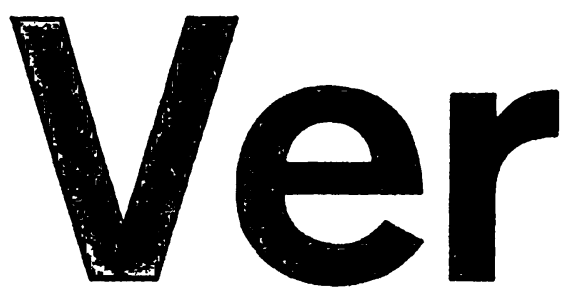

Kontrollplasmen für den normalen und therapeutischen Bereich

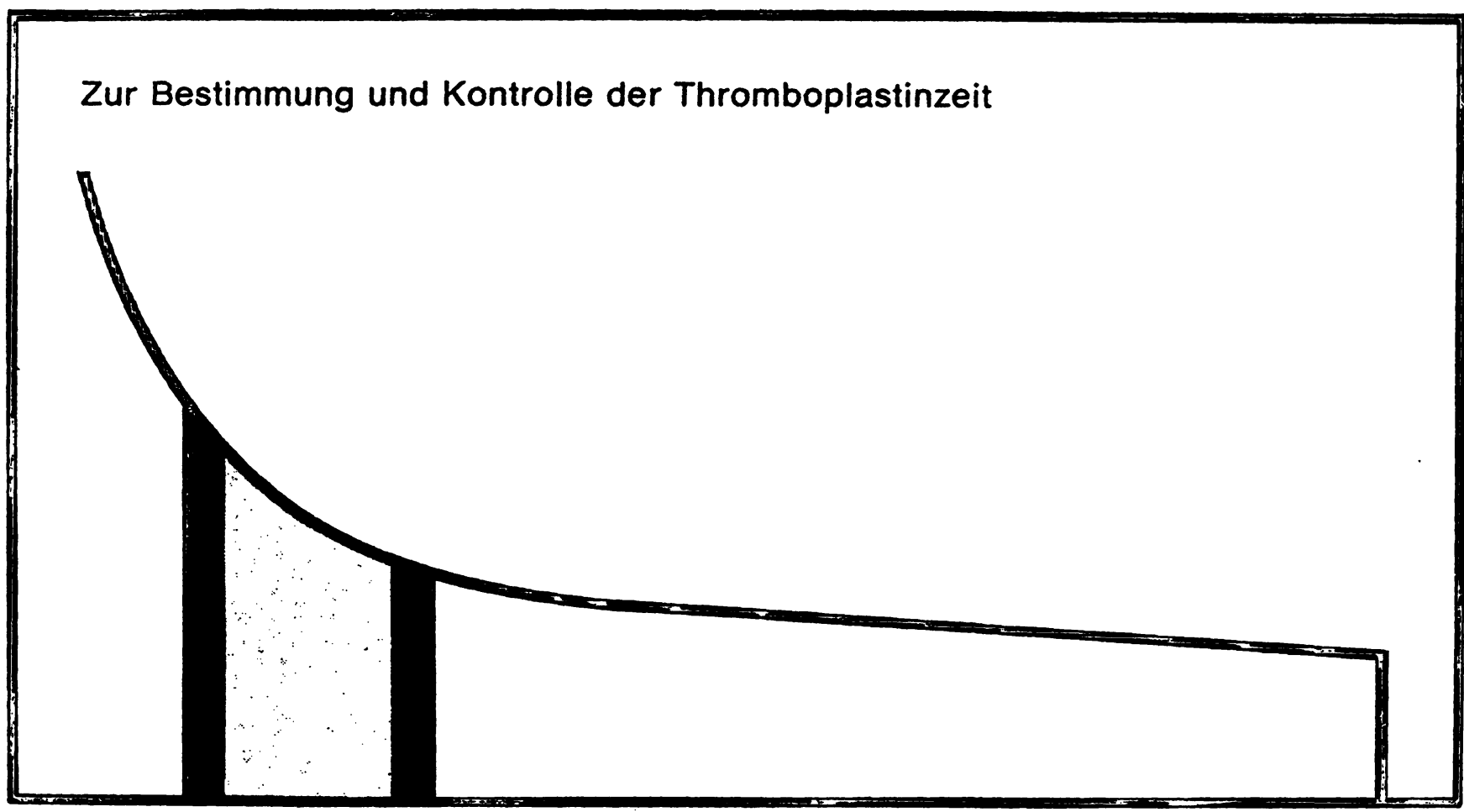

옹

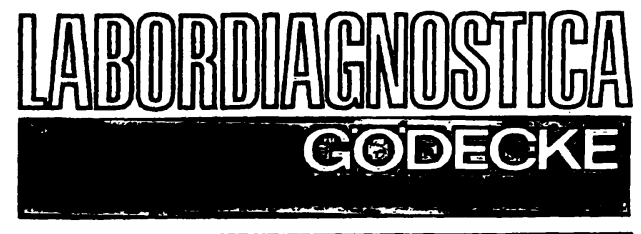

Vertrieb für Österreich: Pharmazeutische Fabrik MONTAVIT GmbH

Absam

A-6060 Solbad Hall (Tirol)
Cosmopharm AG $\mathrm{CH}-8040$ Zürich

Zimmerlistraße 6
Vertrieb für die Schweiz: 


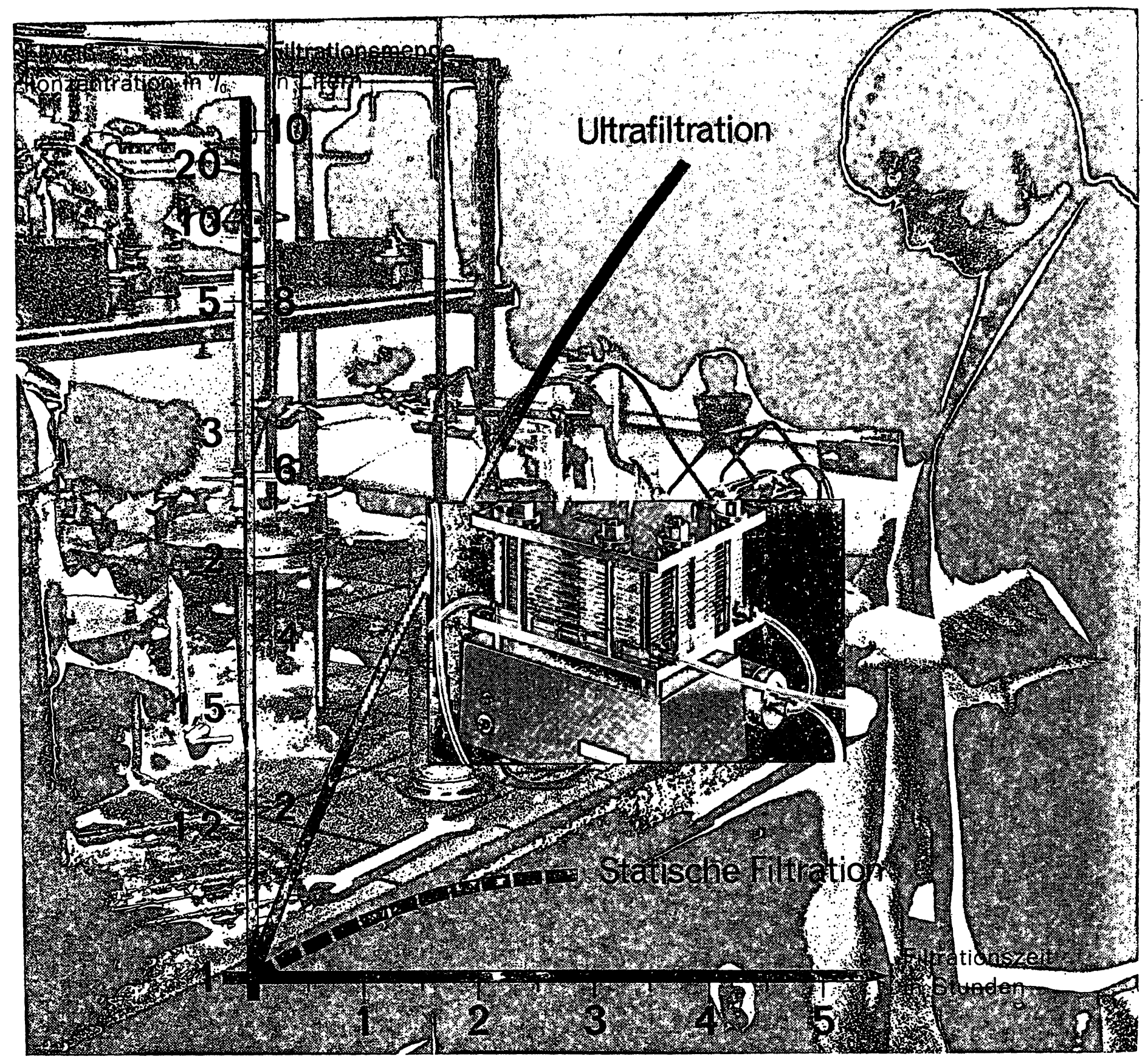

\section{Hochmolekulare Stoffe schnell konzentrieren!}

30 Liter 1\%ige Proteinlösung in 8 Stunden auf $20 \%$ anreichern! Das war bisher nicht möglich.

Doch wir haben eine Lösung gefunden: In unserem neuen Ultrafiltrationsgerät überströmt die zu filtrierende Flüssigkeit das Membranfilter tangential. Das verhindert die Ablagerung fester Stoffe auf dem Filter und den dadurch hervorgerufenen raschen Leistungsabfall.

Wenn Sie mehr darüber wissen wollen, schreiben Sie uns bitte. Wir schicken Ihnen gern ausführliches Informationsmaterial.

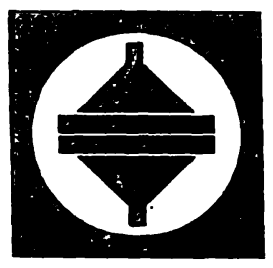

\section{Sartorius-Membranfilter GmbH}


chloroform/ethylacetate/petroleum ether (b. p. $60^{\circ}$ ) 50:45:5 (v/v). The testosterone standards were located with ultraviolet light. The silica in appropriate areas was loosened with razor blades and aspirated by vacuum into Pasteur pipettes plugged with methanolwashed glass wool. Testosterone was then eluted with $4 \mathrm{ml}$ methanol. The residue was dried under air and redissolved in $1 \mathrm{ml}$ methanol. An aliquot of $0.2 \mathrm{ml}$ was taken for recovery and counted for $20 \mathrm{~min}$.

Water blanks and steroid-free plasma blanks, prepared by treating plasma with activated charcoal, were included in each assay and handled in the same way as plasma samples.

\section{Radioimmunoassay}

Each assay was performed in duplicate. An aliquot of $0.1 \mathrm{ml}$ (or $0.2 \mathrm{ml}$ if low testosterone levels were expected) was pipetted into $10 \times 75 \mathrm{~mm}$ disposable glass tubes with LANG-LevY micro pipettes.

Two stock solutions were used for the standard values. Solution 1 contained $1 \mathrm{pg}$ testosterone per $1 \mu \mathrm{l}$ methanol, solution 2 contained $1 \mathrm{ng}$ testosterone per $10 \mu \mathrm{l}$ methanol. Standard values of $0.025,0.05,0.1,0.2$, and $0.5 \mathrm{ng}$ were pipetted from solution 1 into the assay tubes and standard values of 1.0, 2.0, 5.0 and $10.0 \mathrm{ng}$ from solution 2.

All tubes - samples and standards - were then taken to dryness under an air jet. Two empty tubes were added for zero values.

Each tube then received $10,000 \mathrm{cpm}$ testosterone-[1,2-3 $\mathrm{H}]$ (equivalent to $80 \mathrm{pg}$ testosterone) in $0.5 \mathrm{ml}$ diluent. This was followed by $0.5 \mathrm{ml}$ antiserum to a dilution of $1 / 12500$, giving a final dilution of $1 / 25000$ in the assay tube. Cornwall semiautomatic syringes were used for pipetting of these two solutions.

The tubes were then agitated on a Vortex mixer and incubated for 18 hours at $4^{\circ} \mathrm{C}$. Following incubation, $0.2 \mathrm{ml}$ of the dextran coated charcoal solution was added to each tube with a Cornwall semiautomatic syringe. This procedure was performed at $4^{\circ} \mathrm{C}$. The tubes were mixed on a Vortex mixer and centrifuged for $15 \mathrm{~min}$. at $2000 \mathrm{~g}$ and $4^{\circ} \mathrm{C}$.

The supernatant was decanted into counting vials containing $2.5 \mathrm{ml}$ dioxane, followed by $10 \mathrm{ml}$ scintillation liquid. The vials were chilled to $4^{\circ} \mathrm{C}$ and counted until 10,000 counts were accumulated.

\section{Calculation of results}

A logit transformation was used for calculation of the results $(12,13)$. The sample values were extrapolated from a straight line standard curve, which was obtained by plotting the logit of $(B-N) /\left(B_{0}-N\right) \times 100$ against the logarithm of the dose $(B=$ antibody bound labeled testosterone in cpm; $B_{0}=$ antibody bound labeled testosterone at dose zero in $\mathrm{cpm} ; \mathrm{N}=$ nonspecific bound labeled testosterone in cpm) (example in Fig. 1). The assays were calculated by the computer program of RODBARD and LEWALD (14). The standard curves were linear between 0.025 and $10.0 \mathrm{ng}$.

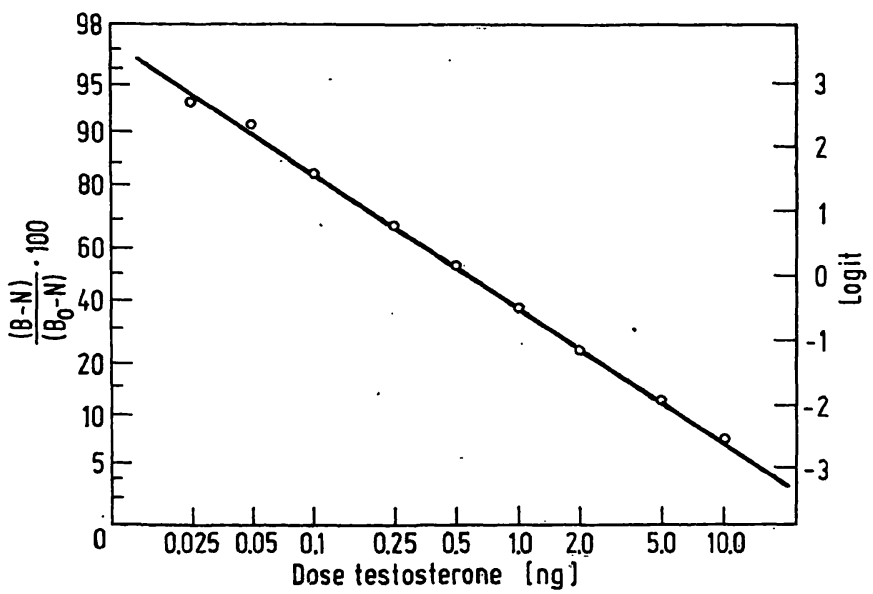

Fig. 1

Standard curve in logit transformation. Ordinate $=\mathrm{B} / \mathrm{B}_{0}$ on logitscale. ( $B=$ antibody bounded labelied, $B_{0}=$ antibody bound unlabelled testosterone)

\section{Results}

\section{Antiserum}

The antigenic response of the six immunized animals was monitored weekly by determination of the serum dilution required to bind $50 \%$ of $10000 \mathrm{cpm}$ testosterone-[1,2- $\left.{ }^{3} \mathrm{H}\right]$. All six rabbits produced antibodies. As early as 4 weeks after immunization titers of $1 / 16000$ and $1 / 25000$ were observed in two animals. Over a period of 10 weeks a steady increase of the titers to dilutions of $1 / 128000$ was observed. There was no significant difference between animals immunized with testosterone-3-albumin or testosterone-3-hemocyanin conjugates.

All assays included in this paper were performed with an antiserum obtained 4 weeks after immunization. The serum was used at a final dilution of $1 / 25000$.

The antiserum was preserved with $0.1 \%$ Na-azide (final concentration)and stored at $4^{\circ} \mathrm{C}$. No deterioration of binding affinity or titer has been observed over a period of 9 months.

The effect of time on the antigen/antibody reaction is shown in Figure 2. At high antigen concentrations equilibrium is reached faster than at low concentrations. Overall, the curves flatten out after 10 hours. Therefore, 10 to 20 hours are required for incubation.

\section{Specificity}

The specificity of the antiserum was investigated by adding other steroids to a solution containing labelled testosterone and antiserum. The relative binding affinity is the ratio of the amount of steroid required to displace $50 \%$ of labelled testosterone to the amount of testosterone required, multiplied by 100 . Dihydrotestosterone was equivalent to testosterone. The relative binding affinities of other possible contaminants were: epitestosterone $0.1 \%$, androstenediol $1.6 \%$, and androstenedione $0.3 \%$. All other C-18, C-19 and C-21 steroids investigated had less than $0.05 \%$ cross reactivity (Fig. 3 and 4).

In the preparation of the samples prior to radioimmunoassay, dihydrotestosterone is completely separated from testosterone by thin layer chromatography.

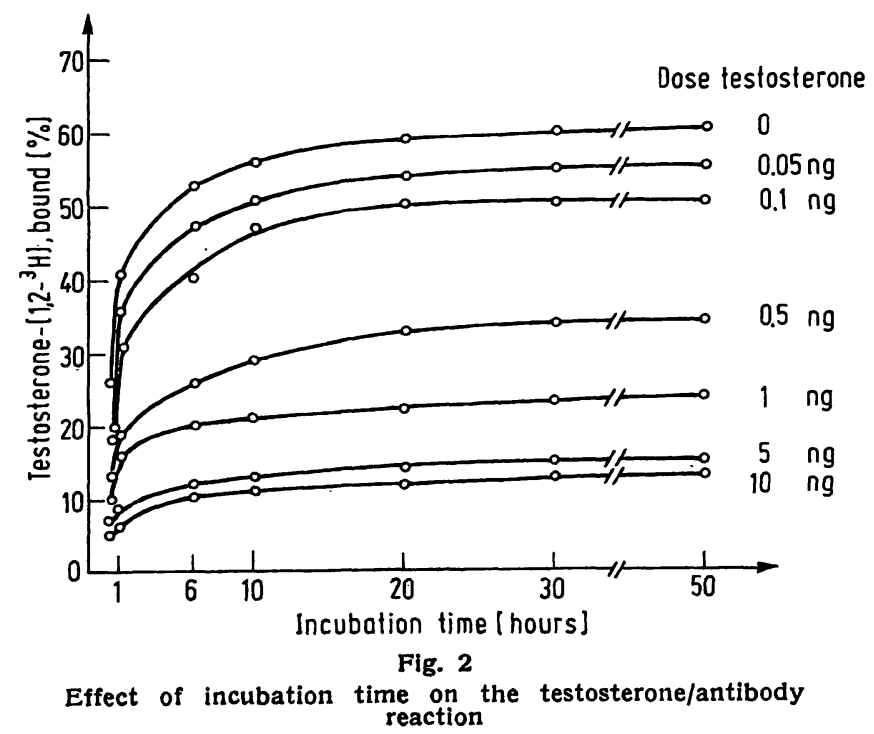



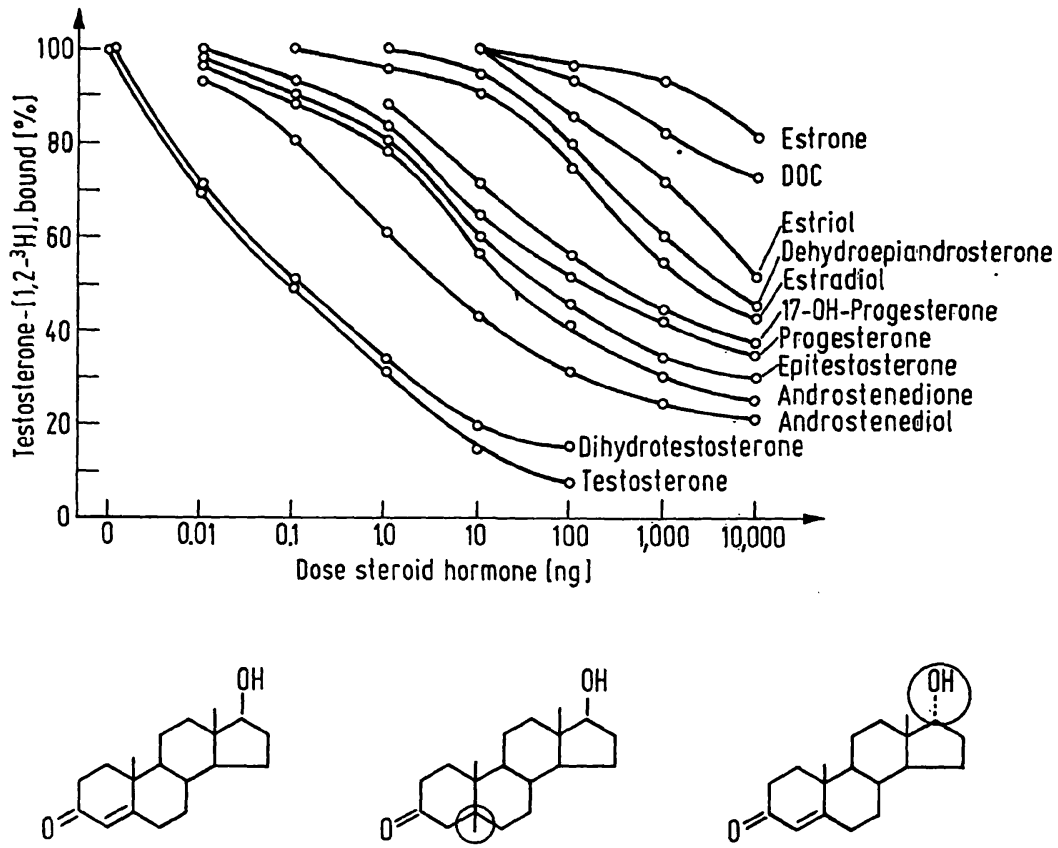

Testosterone $100 \%$
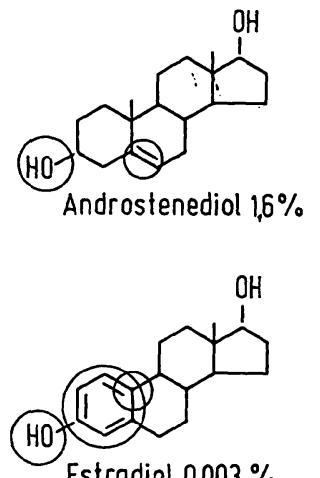

Estradiol $0.003 \%$

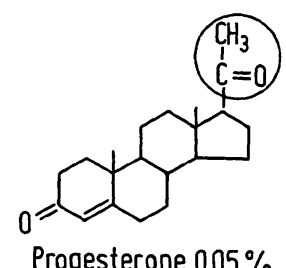

Progesterone $0.05 \%$<smiles>O=C1CCC23CCC4CC(CCC14)C2CCC3O</smiles>

Dihydrotestosterone $100 \%$

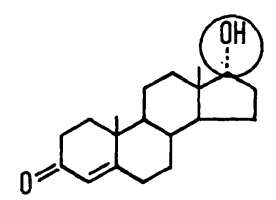

Epitestosterone $0.1 \%$<smiles>O=C1C=C2CCCC3C(CC2)C(CCC32CCCC2)C2(CCCCC2)C1</smiles>

(HO)

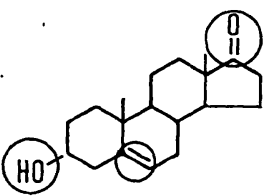

Androstenedione $0,3 \%$ Dehydroepiandrosterone $0.002 \%$
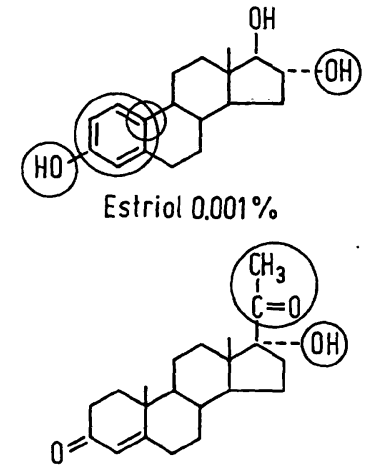

$17-\mathrm{OH}$-Progesterone $0.03 \%$ Deoxycorticosterone $<0.001 \%$
(H0)
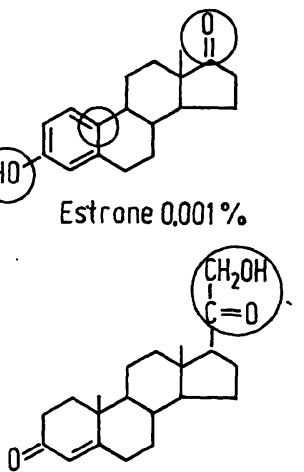

exycorticosterone $<0.001 \%$

\section{Fig. 3}

Cross reaction of the testosterone antiserum with other steroids. Ordinate: antibody bound labelled testosterone as percent of $\mathrm{cpm}$ bound in absence of unlabelled ligand
Fig. 4

Structural formulas and relative binding affinity of the steroids investigated for cross reactivity. Circles indicate the parts of the molecule, which are different from testosterone

\section{Affinity constant, binding capacity and sensitivity}

SCATCHARD plots (15) were constructed for five dose response curves. In all cases, there was significant nonlinearity, indicating the presence of at least two "orders" of antibodies. Using the approximate, graphical parameter fitting method of BERSON and YALOw (16), the affinity constant $K$ of the high affinity antibodies was estimated to be $4 \times 10^{9}$ liter $/$ mole. The affinity constant for the low affinity antibodies was approximately $2 \times 10^{8} \mathrm{liter} / \mathrm{mole}$. The high affinity antibodies appeared to constitute about $25 \%$ of the total binding capacity. "The total binding capacity was $0.1 \mu$ mole/liter for the $1 / 25000$ dilution of the antiserum, which would correspond to a binding capacity of $2.5 \mu$ mole/liter in the original undiluted serum.

The binding affinity of the antibody of $\mathrm{K}=4 \times 10^{9}$ liter/mole implies a theoretical sensitivity of $25 \mathrm{pg}$ per assay tube, using the approximation that the least detectable dose is $0.1 / \mathrm{K}$ (17). The blank values obtained from water or steroid free plasma (charcoal treated) were between 0 and $10 \mathrm{pg}$ and were not subtracted from the sample values. $25 \mathrm{pg}$ testosterone were significantly different from 0 .

\section{Precision}

The within-assay precision was estimated by 9 replicate determinations of a sample under $1 \mu \mathrm{g} / 1$ and duplicate determinations of 17 samples varying from 5.0 to $10.0 \mu \mathrm{g} / \mathrm{l}$. The coefficient of variation (c. v.) for the low concentration was $10.3 \%$ and for the high concentration $9.6 \%$.

Between-assay precision was determined by carrying a sample from a low level pool through 6 assays and a sample from a high level pool through 9 assays. The 
c. v. for the first sample was $19 \%$ and for the second $10.8 \%$.

\section{Accuracy}

The recovery of testosterone- $\left[1,2-{ }^{3} \mathrm{H}\right]$ from 66 samples was $70.3 \pm 6.6 \%$ (s. d.). The recovery of unlabelled testosterone added to water was estimated from 16 values in the range of 0.05 to $1.0 \mathrm{ng}$ per assay tube. The ratio of testosterone found to that added was $100 \pm 6 \%$. For 20 values in the range of 0.1 to $1.0 \mathrm{ng}$ added to plasma the ratio of found to added was $101 \pm 12 \%$.

\section{Plasma values}

The mean plasma testosterone value of 21 normal men, age 21 to 44 years, was $6.37 \pm 1.88$ (s. d.), range $3.20-9.52 \mu \mathrm{g} / \mathrm{l}$ testosterone. The mean plasma value of 7 normal women, age 19 to 22 years, was $0.57 \pm 0.20$, range 0.41 to $0.98 \mu \mathrm{g} / \mathrm{l}$. In a normal man plasma values decreased from $8.70 \mu \mathrm{g} / 1$ to $0.60 \mu \mathrm{g} / 1$ under massive estrogen treatment and rose to $11.20 \mu \mathrm{g} / \mathrm{l}$ after HCG stimulation.

\section{Discussion}

In recent years useful methods for the measurement of testosterone in plasma based on competitive protein binding have been developed (for review see (18) and (19)) and clinical studies on a larger scale were thus facilitated (e. g. (20)). Since the reliability criteria of these methods are satisfactory, it is pertinent to question the necessity of radioimmunoassays for testosterone.

The binding characteristics between testosterone and serum albumin, cortisol binding globulin, testosterone binding globulin and the present antiserum are compared in Table 1. The binding affinity (equilibrium constant of association) for the high affinity component of the present antiserum was $4 \times 10^{9} \mathrm{liter} / \mathrm{mole}$. This is approximately 10 -fold higher than reported values for the affinity of testosterone for testosterone binding globulin (21). The 10-fold increase in affinity constant obtained by use of the present antiserum results in a 10-fold reduction of the least detectable concentration compared to competitive protein binding methods. This makes it possible, for example; to measure testosterone in $0.2 \mathrm{ml}$ of normal female plasma. In addition, the antibody facilitates the establishment of a standard curve over a wide dose range, 0.025 to $10.0 \mathrm{ng}$, in this case.

Tab. 1

Binding characteristics between testosterone and albumin, cortisol binding globulin, testosterone binding globulin and the present high aftinity antibody

\begin{tabular}{lcr}
\hline & $\begin{array}{c}\text { Binding affinity K } \\
\text { (Iiter/mole) }\end{array}$ & $\begin{array}{c}\text { Binding capacity } \\
\text { (mole/liter) }\end{array}$ \\
\hline Albumin & $2 \times 10^{4}$ & $4 \times 10^{-1}$ \\
Cortisol binding globulin & $5 \times 10^{\circ}$ & $1.5 \times 10^{-1}$ \\
Testosterone binding globulin & $2 \times 10^{\circ}$ & $2 \times 10^{-1}$ \\
Antibody & $4 \times 10^{\circ}$ & $2.5 \times 10^{-0}$ \\
\hline
\end{tabular}

In our method the within-assay precision for low and high concentrations is essentially the same. ${ }^{-}$This is achieved by taking a larger sample aliquot, when low levels are anticipated and thus shifting the reading to a precise region of the standard curve.

Furthermore, the antibody offers greater specificity than testosterone binding globulin. Testosterone binding globulin generally shows high cross reactivity with other $17 \beta$-hydroxy-steroids (18), whereas the antibody used in this method cross reacts essentially with dihydrotestosterone alone. It should be pointed out, however, that antibodies against the same hapten may vary considerably in specificity (22). This may explain, why FuruYama and coworkers (8) using an antigen prepared in the same way as in the present method, found only a $48 \%$ cross reactivity with dihydrotestosterone. Generally, it would appear, that the closer the structural changes are to the site of conjugation - i. e., the 3 positions of testosterone - the less likely that they are to be recognized by the antibody, as can be seen in Figure 4.

The new immunization technique applied to the production of testosterone antibodies appears far superior to conventional methods. Useful antibodies are obtained as early as 4 weeks after immunization. Additionally, higher titers are obtained, and less antigen is required. Two testosterone-protein conjugates were used as immunogens: testosterone-3-albumin and testosterone-3-hemocyanin. Hemocyanin, the oxygen transporting protein of crustaces, is well known for its high antigenic potency, but so far only has been applied by Gross and coworkers (23) to produce antisera against steroid hormones. In our experiments, however, nosubstantial difference between antisera against testosterone-3-albumin and testosterone-3-hemocyanin was observed.

\section{Acknowledgements}

We are grateful to Dr. M. B. LipSETr, who provided helpful suggestions and critical review of the manuscript, and to Dr. D. RODBARD, who assisted with the statistical analysis.

\section{Announcement}

The testosterone antiserum is available and may be supplied to interested investigators on application to:

Dr. E. Nieschlag
II. Medizinische Univ.-Klinik
Mooren Str. 5
D 4 Düsseldorf
Germany
or
Dr. M. B. Lipsett
Reproduction Research Branch
National Institute of Child
Health and Human Development
Bethesda
Maryland 20014

Dr. E. Nieschlag

Mooren Str. 5

D 4 Düsseldorf

Germany

Dr. M. B. Lipsett

Reproduction Research Branch

National Institute of Child

Bethesda

Maryland 20014 


\section{. References}

1. Mooser, H. and R. K. Grilliches, Schweiz. Zschr. Allg. Path. Bakt. 4, 375 (1941). - 2. ERLANGer, B. F., F. BoreK, S. M. Beiser and S. Lieberman, J. biol. Chemistry 228, 713 (1957). 3. Abraham, G. J., J. Clin. Endocr., Springfield 29, 866 (1969). 4. Mikhair, G., C. H. Wu, M. Ferin and R. L. Vande Wiele, Steroids 15, 353 (1970). - 5. Gurpide, E., M. E. Giebenhain, L. Tseng and W. G. Kelly, Amer. J. Obstet. Gynec. 109, 897 (1971). - 6. Yoshizawa, J. and J. Fishman, J. Clin. Endocr., Springfield 32, 3 (1971). - 7. Mayes, D., S. Furuyama, D. C. Kem and C. A. Nugent, J. Clin. Endocr., Springfield 30, 682 (1970). 8. Furuyama, S., D. Mayes and C. A. Nugent, Steroids 16,415 (1970). - 9. Furuyama, S. and C. A. Nugent, Steroids 17, 663 (1971). - 10. Vaughan, J. R. and R. L. Osato, J. Amet. chem. Soc. 74, 676 (1952). - 11. Vaitukaitis, J., J. B. RobBins, E. Nieschlag and G. T. Ross, J. Clin. Endocr., Springfield 33, 988 (1971). - 12. RodBard, D., W. BRIDSON and P. L. RAYFord, J. Laborat. Clin. Med., St. Louis 74, 770 (1969). - 13. WoMBACHER, H. and E. Nieschlag, this journal 9, 136 (1971). - 14. Rodbard,
D. and J. E. Lewald, in E. Diczfalusy (ed.), "Steroid Aassy by Protein Binding", Stockholm (1970) p. 79. - 15. Scatchard, G., Ann. N. Y. Acad. Sci. 51, 660 (1949). - 16. Berson, S. A. and R. S. YAlow, J. Clin. Invest. 38, 1996 (1959). - 17. Ports, J. T., L. M. Sherwood, J. L. H. O'RTordan and G. D. Aurbach, Adv. Int. Med. 13, 183 (1967). - 18. Vermeulen, C. A. and D. Mayes, in E. Diczfalusy (Ed.), "Steroid Assay by Protein Binding", Stockholm p. 239 (1970). - 19. Nugenr, C. A. and D. MaYes, in E. Diczfalusy (Ed.), "Steroid Assay by Protein Binding", Stockholm p. 257 (1970). - 20. NreschlaG, E., M. ROHR, H. WOMbacher and C. Overzier, Klin. Wschr. 49, 91 (1971). - 21. Vermeulen, A., L. Verdonck, M. VAN DER Straeten and N. Orie, J. Clin. Endocr., Springfield 29, 1470 (1969). - 22. Pressman, D. and A. L. Grossberg, in Peton, F. G. and B. V. Caldwell (Eds.), "Immunologic Methods in Steroid Determination", New York (1970) p. 1. - 23. Gross, S. J., D. H. Campeell and H. H. Weethall, Immunochem. 5, 55 (1968).

Dr. E. Nieschlag II- Medizinische Uniniv.-Klinik 4000 Düsseldorf

Moorenstr. 5 
Arbeitsmethoden der medizinischen und naturwissenschaftlichen Kriminalistik

Herausgeber: Prof. Dr. med. et phil. Emil Weinig, Erlangen und Professor Dr. med. Steffen Berg, Göttingen

\section{Neuerscheinung}

\section{Band 11 Blutalkohol}

\section{und Blutwassergehalt}

Methodik - Theorie - Praxis

Von Hans-Friedrich Brettel

Professor Dr. med. Am Institut für Rechtsmedizin der Universität Frankfurt a. M.

1972, 98 Seiten mit 7 Abbildungen und 12 Tabellen. Kartoniert 36, - DM.

Das Werk bringt eine Gesamtschau zum Thema und läßt erkennen, daß dieses Gebiet bisher stark vernachlässigt wurde. Dies gilt einerseits für mehr theoretische Fragen wie das Problem des Alkoholverteilungsverhältnisses zwischen Blut und Körper andererseits und vor allem jedoch für die Praxis der Blutalkoholuntersuchung: Auf die Bedeutung von Wassergehaltsbestimmungen bei Zweit- und Nachuntersuchungen sowie bei Alkoholbestimmungen von Leichenblut wird deshalb besonders eingegangen. Im Zentrum des Buches steht die Darstellung der den Serumund Vollblutwassergehalt beeinflussenden Faktoren und der Konsequenzen, die sich aus Störungen der Blutwasserverteilung für das Alkoholverteilungsverhältnis in Blut und Körper ergeben. Damit werden Probleme angeschnitten, die für die forensische Alkoholbegutachtung wichtig sind, was das Buch für jeden Mediziner, der sachverständig sein will, wertvoll macht.

Bitte ausführlichen Prospekt für die Reihe anfordern.

Verlag Max Schmidt-Römhild • 2400 Lübeck 1

\section{Walter de Gruyter Berlin-New York}

\section{Magenoperation und Magenoperierter}

Herausgegeben von HEINRICH BARTELHEIMER, HANS. JOACHIM MAURER, HANS W. SCHREIBER unter. Mitwirkung vọn Kurt Müller-Wieland. Mit 210 Abbildungen und 2 mehrfarbigen

Tafeln. Groß-Oktav. XVI, 489 Seiten. 1969.

Ganzleinen DM 88,-

ISBN $311000819 x$

Weitere Mitarbeiter: Volker Becker Hans Berndt - Kurt Diwok Eduard Farthmann - Hellmuth Freyberger - Max Gülzow - Alfred Gütgemann - Wèrner Koch - Klaus Krentz - Friedrich Kuhlencordt -

Otto Lindenschmidt - Adolf

Luchmann - Fritz Meissner - Walther

Pribilla - Friedrich Stelzner -

Karl-Otto Vorlaender - Egmont

Wildhirt - Ludwig Zukschwerdt

For USA and Canada:

Please send all orders to Walter de Gruyter Inc., 162 Flith Avenue, New York, N.Y. 10010
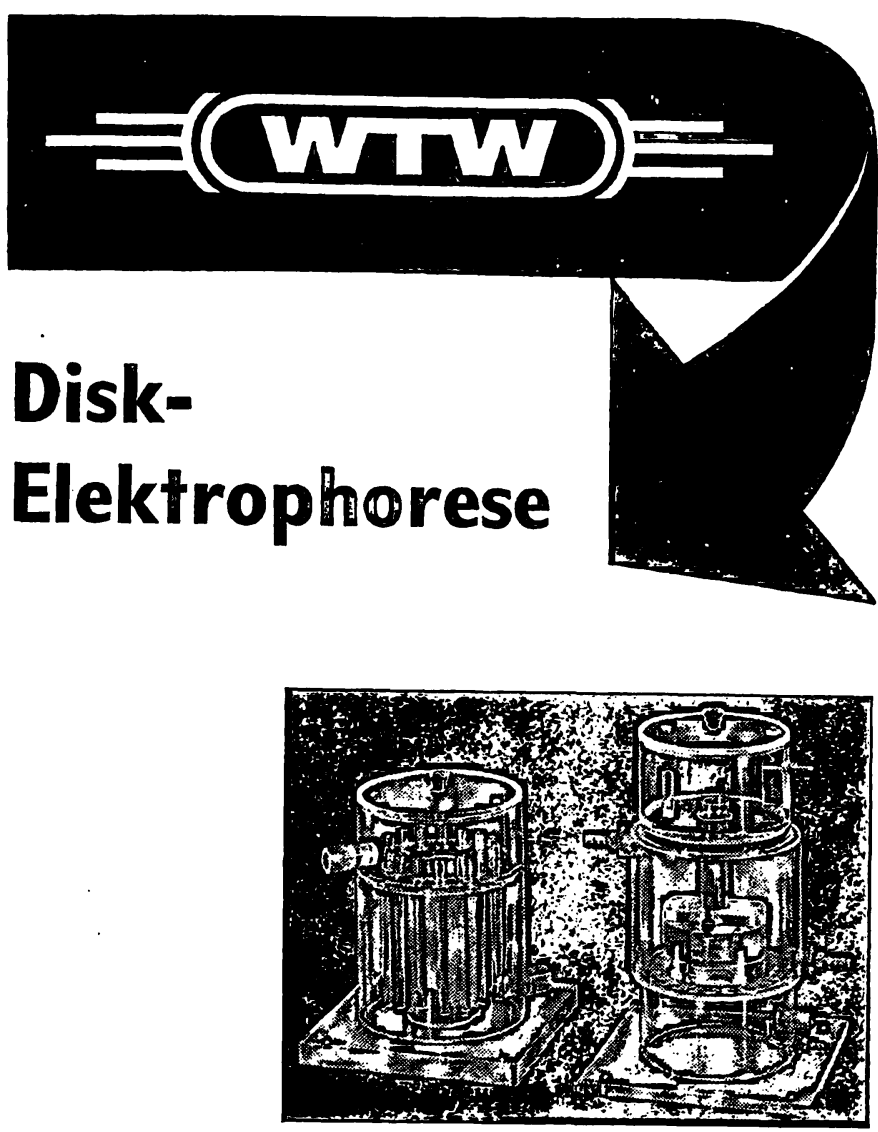

analytische Trennkammer EA 90

mit komplettem oder beliebigem Zubehör

präparative Trennkammer EA 100

mit synchroner Automatik bis zum Fraktionsteiler

Densitometer PHI 3 und PHI 5

für Elektrophorese und Chromatographie
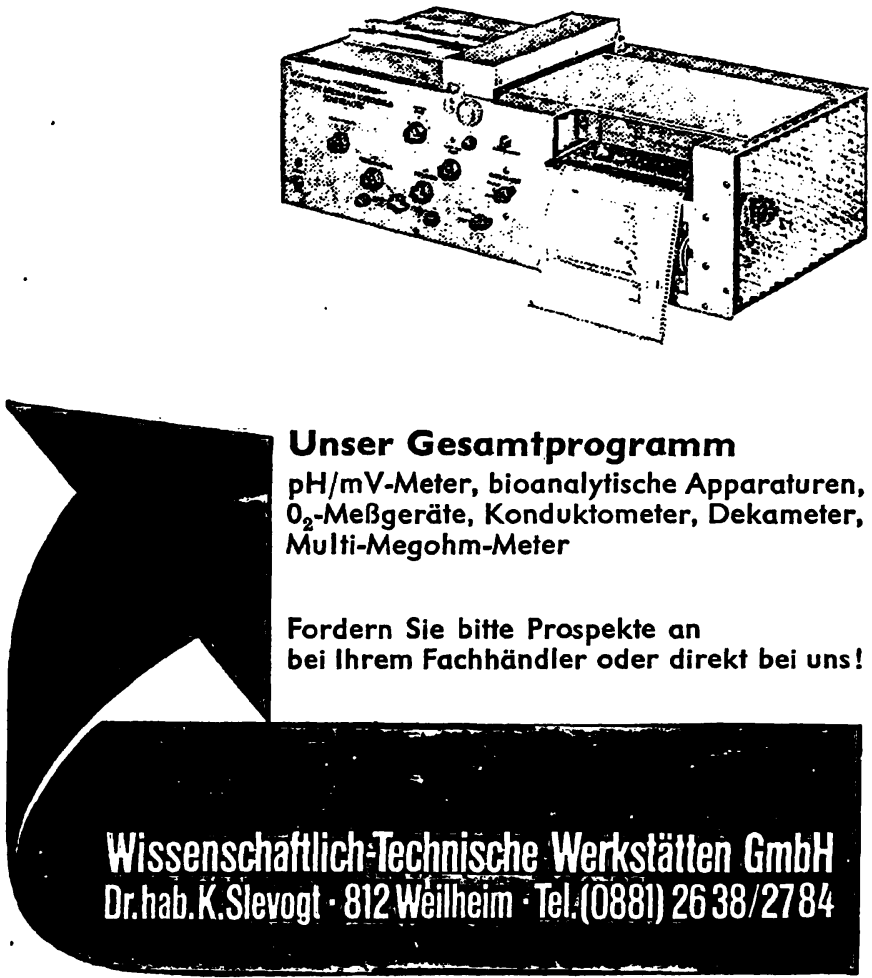

Zur ANALYTICA 72

finden Sie uns in Halle 2, Stand 2102 


\section{Verschiedene Mikrovolumina - in Sekunden abgeben...}

das kann der Hamilton-Aliquanter. Stellen Sie die

Anschläge auf die verschiedenen Volumina ein, verbinden Sie den Saugarm der Spritze mit einem Vakuum und ziehen Sie den.Kolben der Spritze zurück - das ist alles. Die Spritze wird automatisch luftfrei gefüllt. Das Verfahren,iszigëenauer (ca. $\pm 1 \%$ ) und schneller (ca. $15 \mathrm{~s}$ bei 6 Proben) als manuelle Pipettierung oder automatische Dosierung in der Hämatologie, bei Chlorid-Bestimmungen, Vielfach $=$ Enzym-Bestimmungen oder Verdünnüingen. Genaueres erfahrén Sie aus unserem Katalog, den wir Innen auf anfrage gern zuschicken: - Bitte schreiben Sie an Hamilton-Micromesure N.V., Postfach 205, Den Haag, Holland.

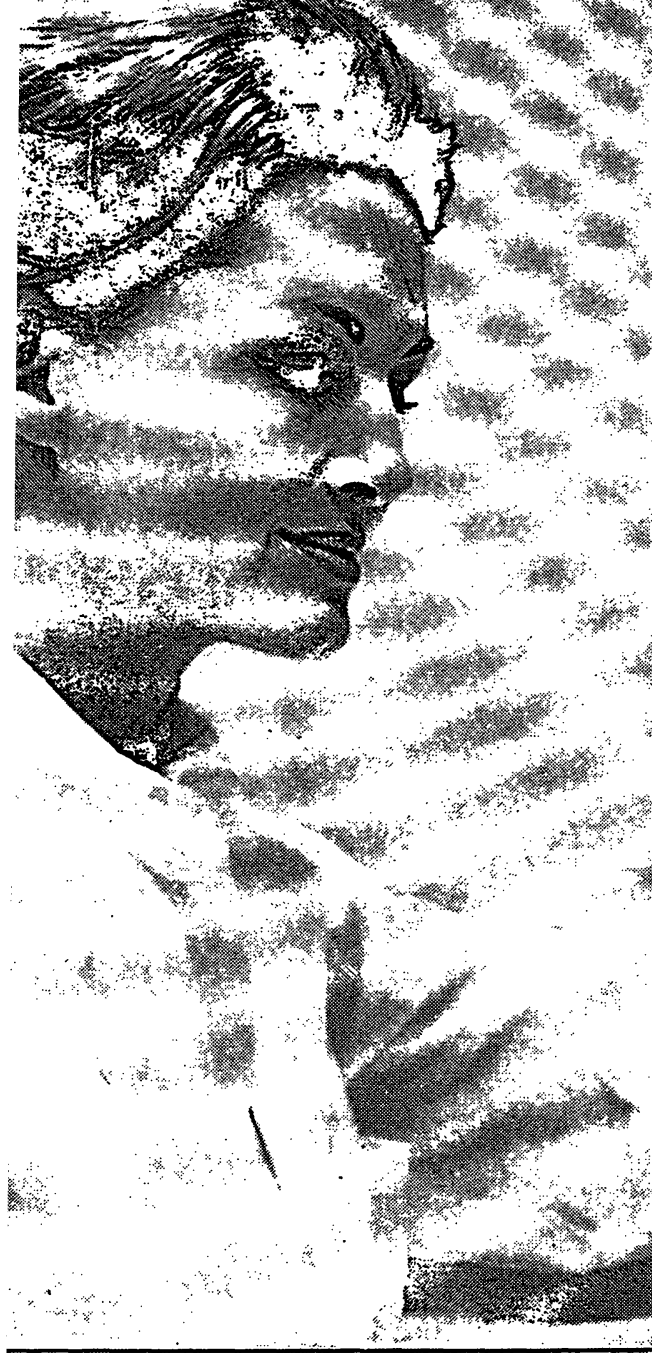

Autorisierter Händler für die BRD: GÜNTHER SGHMIDT Hamburg - Frankfurt

\begin{tabular}{ll} 
Verkauf: & \\
\hline Aachen: & Ludwig Mohren KG \\
Berlin: & H. Windler KG \\
Bonn: & C. Gerhardt \\
Bremen: & H. Jürgens \& Co. \\
Frankfurt: & Will Flscher KG \\
Freiburg: & Bender \& Hobein GmbH \\
Götingen: & Bodo Schmidt \\
Hamburg: & Alfred Hübscher \\
Hannover: & H. Jürgens \& Co. \\
Karlsruhe: & Bender \& Hobein GmbH \\
Kiel: & Erich Eydam \\
München: & Bender \& Hobein GmbH \\
&
\end{tabular}
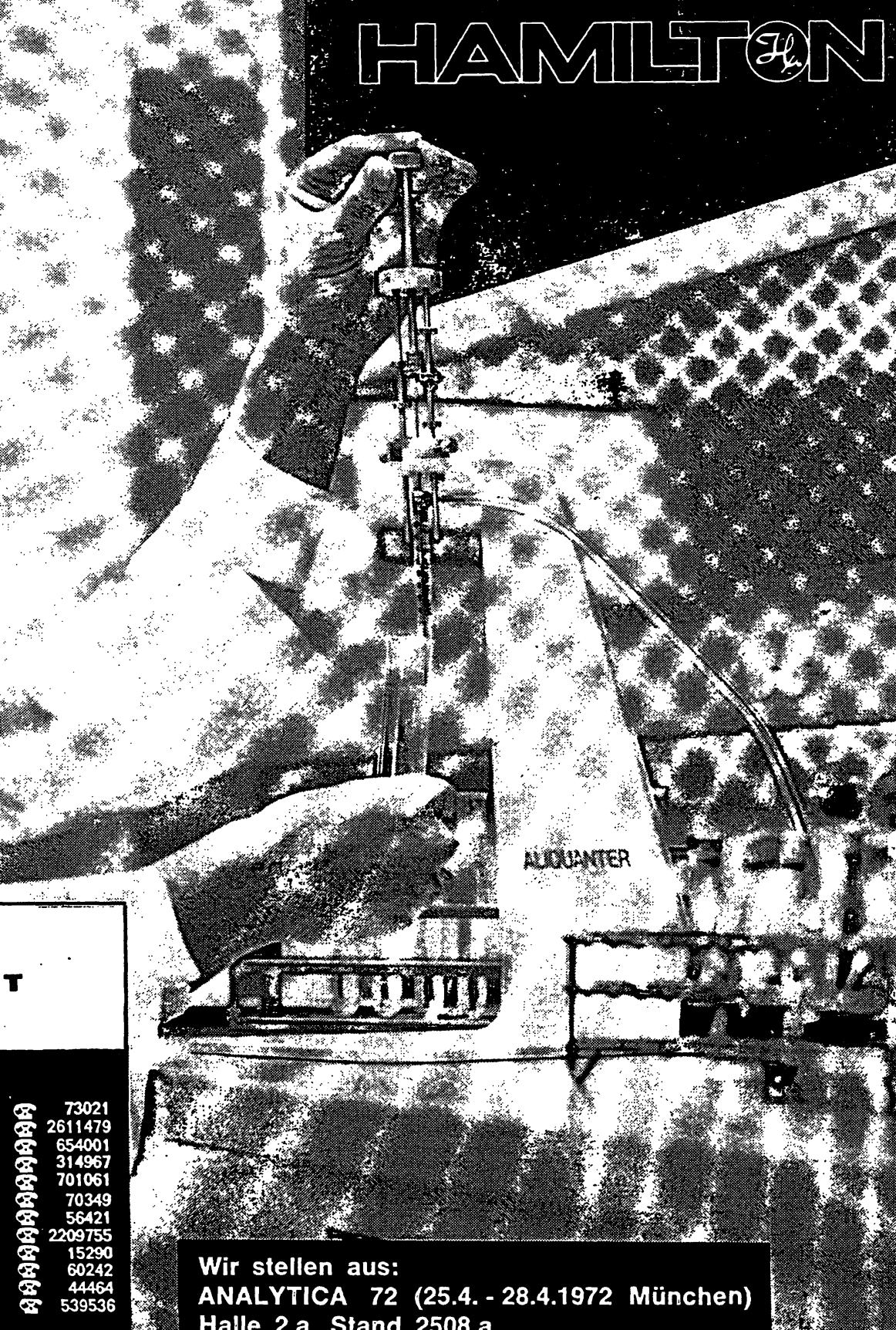

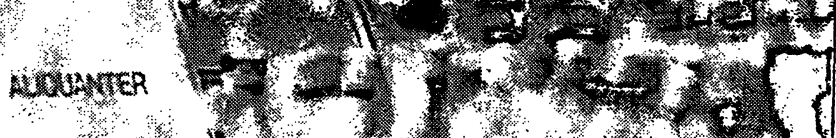
.

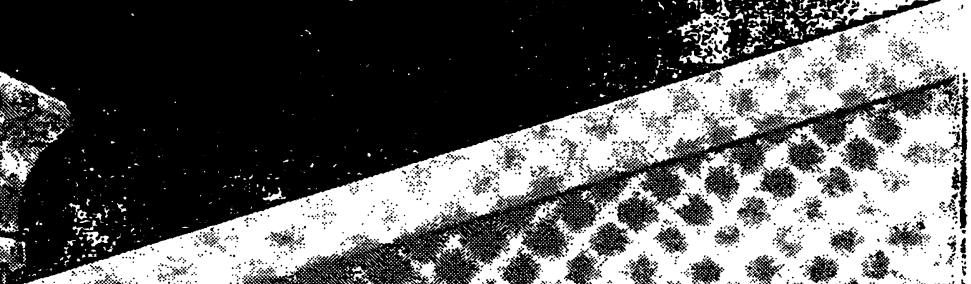

